\title{
An index for estimating the potential impact on the environment of the pollutant content in aquatic populations
}

\author{
Oscar RAVERA \\ CNR - Institute of Ecosystem Study, L.go Tonolli 50, 28922 Verbania Pallanza, Italy \\ e-mail corresponding author: o.ravera@ise.cnr.it
}

\begin{abstract}
The so-called "Concentration factor" (C.F.) should express a direct positive relationship between the concentration of a pollutant (e.g. metals, radioisotopes) in an organism and the concentration of the same pollutant in the water. While this index is very useful in some cases, it cannot give any information on the influence of the biota on its environment, an important topic in research on biogeochemical cycles. A new index (the Influence index) has consequently been developed to quantify the potential influence of the pollutant content in the population biomass on the habitat in which the population lives. The value of this index is calculated as the ratio between the pollutant content in the population biomass per sediment surface unit (e.g. $\left.\mathrm{m}^{2}\right)$ and the concentration of the same pollutant in the water, and is expressed as water volume with the same pollutant concentration as in the water of the population habitat. The value increases with the increase of the pollutant content in the population biomass and the decrease of the pollutant concentration in the water. As an example, some applications of the index to heavy metal contaminations of a freshwater mussel (Unio pictorum mancus) population are described.
\end{abstract}

Key words: concentration factor, influence index, heavy metals, fresh water mussel, biomass

Several aquatic animal and plant species (e.g., molluscs, fish, macrophytes) are referred to as bioindicators of accumulation because they can concentrate even toxic pollutants in their bodies without suffering any apparent damage. This ability has been used to establish a ratio between the pollutant concentration in the organism and that in the water. The use of this ratio, known as the concentration factor (C.F.), shows clearly that a number of species concentrate pollutants (e.g., radioisotopes, biocides, metals) in their bodies up to $10^{3}-10^{5}$ times the concentrations in the water in which they live. As well as having ecological significance, this information is also important in practice. For example, before the 1960s national and international legislation on radioactive and toxic pollution focused essentially on pollutants in the water. Thanks to studies on accumulator species, legislation now covers not only water, but also these species and particularly those used as food by man and domestic animals (e.g. Recht 1969). On the other hand, the C.F. does not consider either the population biomass or its pollutant contents, essential variables for estimating the influence of the population on its environment.

It is important to estimate the pollutant content in the population biomass because it represents the amount of pollutant immobilized by the organisms during their life, which is equivalent to that transferred to the environment after their death.

These considerations prompted the development of a new index based on the ratio between the pollutant content in the population biomass and the concentration of the same pollutant in the water of the environment in which the population lives.
This index, which due to its function I have called the "Influence index" (I.i.), can give rough information on the potential influence on the environment of the pollutant content in a population in relation to the concentration of the same pollutant in the water.

$$
\text { I.i. }=\mathrm{A} \times \mathrm{B} / \mathrm{C} \times 10^{3}
$$

where:

I.i. = volume $\left(\mathrm{m}^{3}\right)$ of water with the pollutant concentration equal to that of environmental water

$\mathrm{A}=$ pollutant concentration in the organism $\left(\mu \mathrm{g} \mathrm{g}^{-1} \mathrm{dw}\right)$

$\mathrm{B}=$ dry weight of the biomass $\left(\mathrm{g} \mathrm{dw} \mathrm{m}^{-2}\right)$

$\mathrm{C}=$ pollutant concentration in the water $\left(\mu \mathrm{g} \mathrm{L}^{-1}\right)$.

This formula can be used to calculate the potential water volume required to dilute the pollutant content in the biomass of a population to the point at which a pollutant concentration equal to that of the environmental water is obtained.

The value of the benthic species biomass relates to the specimens living in $1 \mathrm{~m}^{2}$ of sediment, that of the planktonic species biomass to $1 \mathrm{~m}^{3}$. For example, the index value calculated for calcium in mussel shells from Lake Maggiore is $5.73 \mathrm{~m}^{3}$ of water with a Ca concentration of $26 \mathrm{mg} \mathrm{L}^{-1}$, that is, the same concentration as in the lake water. The Ca content in $5.73 \mathrm{~m}^{3}$ of water amounts to 149 $\mathrm{mg}$, which is the same as the Ca content in the shell biomass of mussels living on $1 \mathrm{~m}^{2}$ of sediment (Tab. 1).

Clearly, at the same pollutant content in the biomass the index value increases as the pollutant concentration in the water decreases. As a consequence, in environments with a low level of contamination the influence of the pollutant content in the biomass is stronger than it is in very polluted environments. The use of this index is 
Tab. 1. Influence index (I.i.) calculated for calcium in soft tissues and shell of Unio pictorum mancus from Lake Maggiore and Lake Candia. A = calcium concentrations in the soft tissues and shell of the mussel; B = biomass (dry weight) of soft tissues and shell; $\mathrm{C}=$ calcium concentrations in filtered water from Lake Maggiore and Lake Candia.

\begin{tabular}{lccccc}
\hline & \multicolumn{2}{c}{ Lake Maggiore } & & \multicolumn{2}{c}{ Lake Candia } \\
\cline { 2 - 3 } \cline { 5 - 6 } & tissue & shell & & tissue & shell \\
\hline $\mathrm{A}\left(\mathrm{mg} \mathrm{g}^{-1}\right)$ & 61 & 365 & & 16 & 365 \\
$\mathrm{~B}\left(\mathrm{~g} \mathrm{~m}^{-2}\right)$ & 39 & 408 & & 14 & 92 \\
$\mathrm{C}\left(\mathrm{mg} \mathrm{L}^{-1}\right)$ & 26 & 26 & & 15 & 15 \\
I.i. $\left(\mathrm{m}^{3}\right)$ & 0.09 & 5.72 & & 0.01 & 2.24 \\
\hline
\end{tabular}

Tab. 2. Seasonal variations of the biomass and the cobalt concentration in soft tissues and shell of Unio pictorum mancus from Lake Maggiore. A = cobalt concentration; B = biomass (d.w.). Cobalt concentration in filtered water $=\mu \mathrm{g} 0.09 \mathrm{~L}^{-1}$.

\begin{tabular}{|c|c|c|c|c|c|}
\hline & \multirow{2}{*}{ Month } & \multicolumn{2}{|c|}{ Soft tissues } & \multicolumn{2}{|c|}{ Shell } \\
\hline \multirow{13}{*}{ 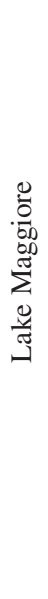 } & & $\begin{array}{c}\mathrm{A} \\
\left(\mu \mathrm{g} \mathrm{g}^{-1}\right)\end{array}$ & $\begin{array}{c}\mathrm{B} \\
\left(\mathrm{g} \mathrm{m}^{-2}\right)\end{array}$ & $\begin{array}{c}\mathrm{A} \\
\left(\mu \mathrm{g} \mathrm{g}^{-1}\right)\end{array}$ & $\begin{array}{c}\mathrm{B} \\
\left(\mathrm{g} \mathrm{m}^{-2}\right)\end{array}$ \\
\hline & June 03 & 0.88 & 47 & 0.84 & 499 \\
\hline & July 03 & 0.85 & 26 & 0.83 & 279 \\
\hline & August 03 & 0.83 & 34 & 0.85 & 358 \\
\hline & September 03 & 0.82 & 36 & 0.79 & 374 \\
\hline & October 03 & 1.01 & 40 & 0.79 & 426 \\
\hline & February 04 & 1.12 & 41 & 0.80 & 425 \\
\hline & March 04 & 0.89 & 36 & 0.78 & 381 \\
\hline & April 04 & 0.94 & 36 & 0.73 & 381 \\
\hline & May 04 & 0.77 & 40 & 0.86 & 449 \\
\hline & June 04 & 0.87 & 39 & 0.81 & 412 \\
\hline & mean $\pm \mathrm{SD}$ & $9.71 \pm 27.86$ & $37.50 \pm 5.46$ & $0.81 \pm 0.04$ & $398.40 \pm 59.09$ \\
\hline & $\% \mathrm{CV}$ & 286.95 & 14.57 & 4.80 & 14.83 \\
\hline
\end{tabular}

obviously limited to aquatic species and particularly to those living permanently in lentic ecosystems. The "Influence index" may be applied to populations of single species and to associated species such as plankton and benthos. In addition, it may be used for organic and inorganic pollutants and nutrient substances. The "Influence index" is useful less for its absolute value than for the possibility it provides for comparing the potential influence of pollutants on an environment exerted by one species from various ecosystems and that of several species living in one environment. It can be a useful tool for following the variations over time of both the physical environment and the biota.

It also makes it possible to quantify the contribution to the index from the biomass and the pollutant concentration in the organism and in the water.

The applications of the index can be illustrated by two examples, involving a freshwater mussel (Unio pic- torum mancus) and some trace metals ${ }^{1}$. Unio pictorum was chosen because the mussel body is made up of two compartments (shell and soft tissues) with very different chemical compositions. In addition, after the mussel's death, the decomposition time of the soft tissues is about two weeks and that of the shell from one to several years, depending on the carbonate concentration in the environment. As a consequence, the metal content in the soft tissues has an effect on the environment in a much shorter time than that in the shell.

The first example focuses on the seasonal variations of the index calculated on the cobalt content in the soft tissues and shell of Unio from Lake Maggiore and Lake Candia in relation to the Co concentration in the lake water (Fig. 1).

The seasonal variations of the biomass and the cobalt concentrations in the soft tissues and shell of mussels from both lakes are not very wide (Tabs 2 and 3). This

${ }^{1}$ The biomass data used in this paper were taken from Ravera et al. (2007a) and those on the metal concentrations from Ravera et al. (2007b). 
1)

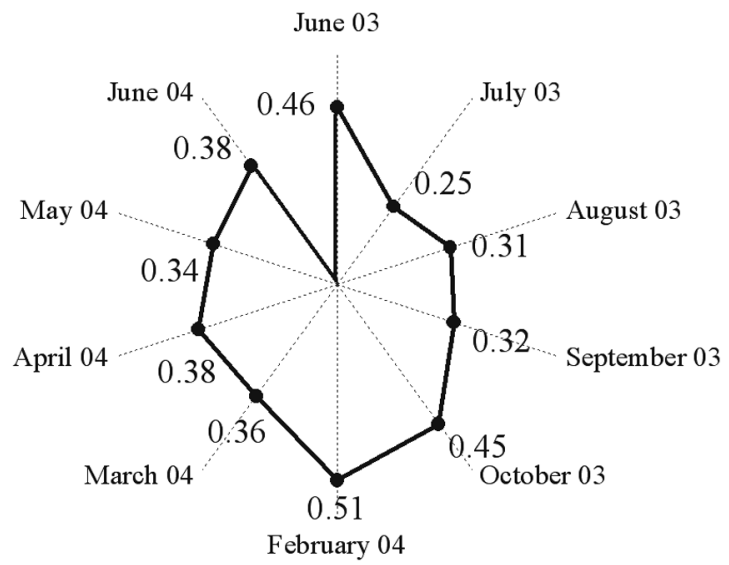

3)

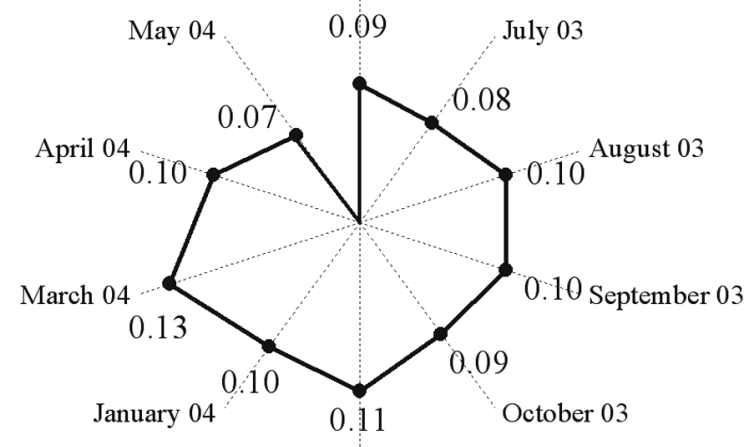

November 03
2)

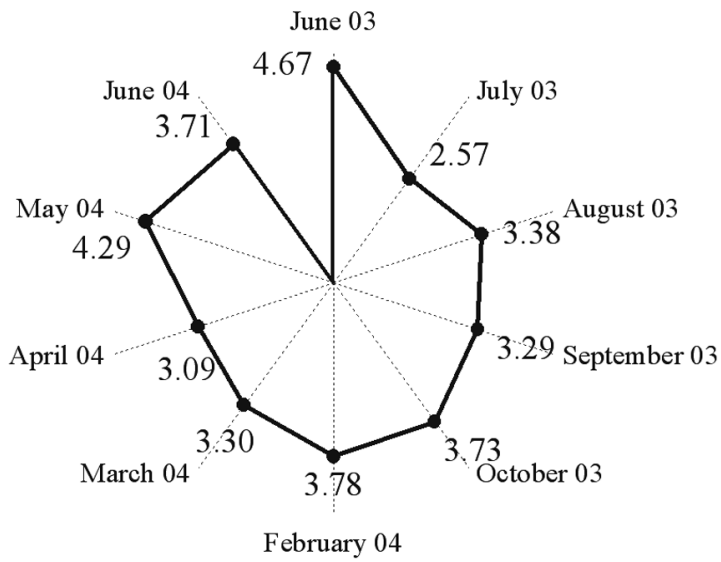

4)

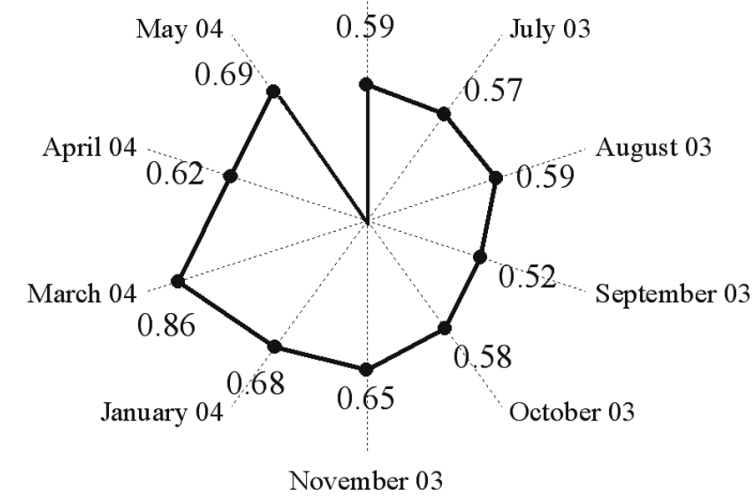

Fig. 1. Seasonal variations of the I.i. (Influence index) expressed in $\mathrm{m}-3$ calculated for cobalt in the soft tissues and shell of Unio pictorum mancus from Lake Maggiore and Lake Candia. 1 = Lake Maggiore, tissues; 2 = Lake Maggiore, shell; 3 = Lake Candia, soft tissues; $\mathbf{4}$ = Lake Candia, shell.

is the consequence of the pluriannual life span of Unio pictorum mancus and the small variations in time of the Co concentrations in the water of both the lakes.

The cobalt concentrations in the soft tissues and shell of mussels from Lake Maggiore are slightly higher than those calculated for Lake Candia mussels, while the tissue and shell biomass of Lake Maggiore mussels is very high in comparison to that of Lake Candia. Because the cobalt concentration in the water is the same in both lakes $\left(0.09 \mu \mathrm{g} \mathrm{L}^{-1}\right)$, it is evident that the higher I.i. values for the soft tissues and shell of Lake Maggiore mussels are essentially due to their greater biomass.

The polygons reported in Figure 1 schematize the seasonal variation patterns of the I.i. values calculated for cobalt in soft tissues and shell mussels from Lake Maggiore and Lake Candia. The shape of the polygons of soft tissues and shell in each lake is very similar, whereas the polygons of one lake are rather different from those of the other.

The second example involves a comparison of the index values, calculated for 4 metals $(\mathrm{Pb}, \mathrm{As}, \mathrm{Ni}, \mathrm{Cr})$, in the same mussel species (Unio pictorum mancus) from two environments: the deep, oligotrophic Lake Maggiore and the shallow, eutrophic Lake Candia (Tabs 4 and 5; Fig. 2). The metal concentrations in tissues and shell of Lake Maggiore mussels are always higher than in those from Lake Candia. The tissue biomass of Lake Maggiore mussels $\left(39 \mathrm{~g} \mathrm{dw} \mathrm{m}^{-2}\right)$ is about 3 times that calculated for Lake Candia $\left(14 \mathrm{~g} \mathrm{dw} \mathrm{m}^{-2}\right)$, and the shell biomass estimated for the former lake $\left(408 \mathrm{~g} \mathrm{dw} \mathrm{m}^{-2}\right)$ is 4 times that of the latter $\left(92 \mathrm{~g} \mathrm{dw} \mathrm{m}^{-2}\right)$. These differences may explain the higher index values for the tissues and shell of Lake Maggiore mussels than those calculated for Lake Candia, in spite of the higher metal concentrations in Lake Maggiore water, except for the Ni index calculated for the tissues, which is higher in Lake Candia.

In conclusion, I believe that this rough attempt to quantify the chemical influence of a population on its environment can contribute positively to biogeochemical studies and their applications. 
Tab. 3. Seasonal variations of the biomass and the cobalt concentration in soft tissues and shell of Unio pictorum mancus from Lake Candia. A = cobalt concentration; B = biomass (d.w.). Cobalt concentration in filtered water $=\mu \mathrm{g} 0.09 \mathrm{~L}^{-1}$.

\begin{tabular}{|c|c|c|c|c|c|}
\hline & \multirow{2}{*}{ Month } & \multicolumn{2}{|c|}{ Soft tissues } & \multicolumn{2}{|c|}{ Shell } \\
\hline \multirow{13}{*}{ 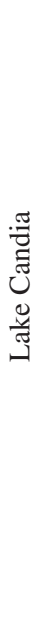 } & & $\begin{array}{c}\mathrm{A} \\
\left(\mu \mathrm{g} \mathrm{g}^{-1}\right)\end{array}$ & $\begin{array}{c}\mathrm{B} \\
\left(\mathrm{g} \mathrm{m}^{-2}\right)\end{array}$ & $\begin{array}{c}\mathrm{A} \\
\left(\mu \mathrm{g} \mathrm{g}^{-1}\right)\end{array}$ & $\begin{array}{c}\mathrm{B} \\
\left(\mathrm{g} \mathrm{m}^{-2}\right)\end{array}$ \\
\hline & June 03 & 0.57 & 14 & 0.56 & 94 \\
\hline & July 03 & 0.57 & 12 & 0.61 & 85 \\
\hline & August 03 & 0.64 & 13 & 0.60 & 89 \\
\hline & September 03 & 0.58 & 15 & 0.54 & 87 \\
\hline & October 03 & 0.56 & 14 & 0.56 & 94 \\
\hline & November 03 & 0.69 & 14 & 0.60 & 97 \\
\hline & January 04 & 0.61 & 15 & 0.59 & 104 \\
\hline & March 04 & 0.77 & 16 & 0.75 & 103 \\
\hline & April 04 & 0.67 & 14 & 0.62 & 91 \\
\hline & June 04 & 0.45 & 14 & 0.65 & 96 \\
\hline & mean $\pm \mathrm{SD}$ & $0.61 \pm 0.09$ & $14.10 \pm 1.10$ & $0.61 \pm 0.06$ & $94.00 \pm 6.31$ \\
\hline & $\% \mathrm{CV}$ & 14.30 & 7.80 & 9.77 & 6.71 \\
\hline
\end{tabular}

Tab. 4. Lead, arsenic, nickel and chrome concentrations (A) in the soft tissues and shell of Unio and in filtered water of Lake Maggiore (C). In addition, the biomass values (B) of soft tissues and shell are reported.

\begin{tabular}{|c|c|c|c|c|c|c|c|}
\hline \multirow{6}{*}{ 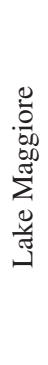 } & & \multicolumn{3}{|c|}{ Soft tissues } & \multicolumn{3}{|c|}{ Shell } \\
\hline & & $\begin{array}{c}\mathrm{A} \\
\left(\mu \mathrm{g} \mathrm{g}^{-1}\right)\end{array}$ & $\begin{array}{c}\mathrm{B} \\
\left(\mathrm{g} \mathrm{m}^{-2}\right)\end{array}$ & $\begin{array}{c}\mathrm{C} \\
\left(\mu \mathrm{g} \mathrm{L}^{-1}\right)\end{array}$ & $\begin{array}{c}\mathrm{A} \\
\left(\mu \mathrm{g} \mathrm{g}^{-1}\right)\end{array}$ & $\begin{array}{c}\mathrm{B} \\
\left(\mathrm{g} \mathrm{m}^{-2}\right)\end{array}$ & $\begin{array}{c}\mathrm{C} \\
\left(\mu \mathrm{g} \mathrm{L}^{-1}\right)\end{array}$ \\
\hline & $\mathrm{Pb}$ & 11.95 & 39 & 0.48 & 0.49 & 408 & 0.48 \\
\hline & As & 9.05 & 39 & 1.36 & 0.52 & 408 & 1.36 \\
\hline & $\mathrm{Ni}$ & 6.95 & 39 & 1.60 & 6.48 & 408 & 1.60 \\
\hline & $\mathrm{Cr}$ & 3.97 & 39 & 0.33 & 0.64 & 408 & 0.33 \\
\hline
\end{tabular}

Tab. 5. Lead, arsenic, nickel and chrome concentrations (A) in the soft tissues and shell of Unio and in the water of Lake Candia (C). In addition, the biomass values (B) of the soft tissues and shell are reported.

\begin{tabular}{|c|c|c|c|c|c|c|c|}
\hline \multirow{6}{*}{ 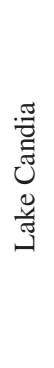 } & & \multicolumn{3}{|c|}{ Soft tissues } & \multicolumn{3}{|c|}{ Shell } \\
\hline & & $\begin{array}{c}\text { A } \\
\left(\mu g g^{-1}\right)\end{array}$ & $\begin{array}{c}\mathrm{B} \\
\left(\mathrm{g} \mathrm{m}^{-2}\right)\end{array}$ & $\begin{array}{c}\mathrm{C} \\
\left(\mu \mathrm{g} \mathrm{L}^{-1}\right)\end{array}$ & $\begin{array}{c}\mathrm{A} \\
\left(\mu \mathrm{g} \mathrm{g}^{-1}\right)\end{array}$ & $\begin{array}{c}\mathrm{B} \\
\left(\mathrm{g} \mathrm{m}^{-2}\right)\end{array}$ & $\begin{array}{c}\mathrm{C} \\
\left(\mu \mathrm{g} \mathrm{L}^{-1}\right)\end{array}$ \\
\hline & $\mathrm{Pb}$ & 2.64 & 14 & 0.29 & 0.26 & 92 & 0.29 \\
\hline & As & 2.68 & 14 & 0.51 & 0.43 & 92 & 0.51 \\
\hline & $\mathrm{Ni}$ & 4.22 & 14 & 1.85 & 5.50 & 92 & 1.85 \\
\hline & $\mathrm{Cr}$ & 1.48 & 14 & 0.12 & 0.46 & 92 & 0.12 \\
\hline
\end{tabular}




\section{Lake Maggiore}

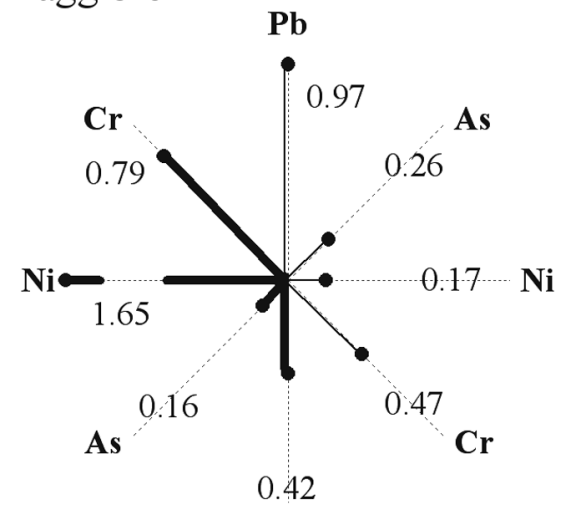

$\mathbf{P b}$

\section{Lake Candia}

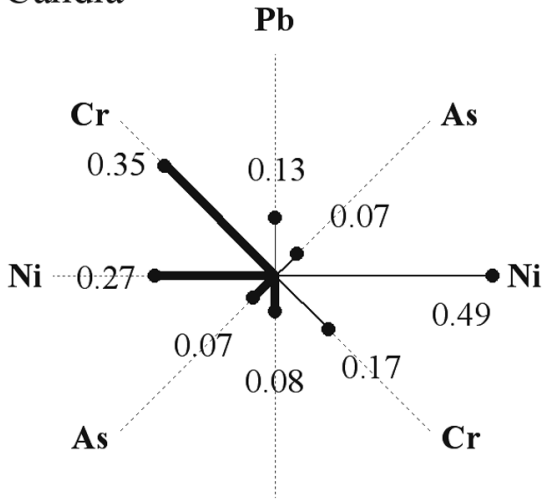

$\mathbf{P b}$

Fig. 2. The "Influence index" (I.i.) values, expressed in $\mathrm{m}^{3}$, calculated for four metals ( $\mathrm{Pb}, \mathrm{As}, \mathrm{Ni}, \mathrm{Cr}$ ) in the soft tissues (thin line) and shell (thick line) of Unio pictorum mancus from Lake Maggiore and Lake Candia.

\section{REFERENCES}

Ravera, O., A. Frediani \& N. Riccardi. 2007a. Seasonal variations in population dynamics and biomass of two Unio pictorum mancus (Mollusca, Unionidae) populations from two lakes of different trophic state. J. Limnol., 66(1): 15-27.

Ravera, O., G.M. Beone, P.R. Trincherini \& N. Riccardi. 2007b.
Seasonal variations in metal content of two Unio pictorum mancus (Mollusca, Unionidae) populations from two lakes of different trophic state. J. Limnol., 66(1): 28-39.

Recht, P. 1969. Principi e metodologia generale per la determinazione della capacità radiologica limite di una rete idrobiologica. C.C.E. Direzione Generale Affari Sociali e Direzione Protezione Sanitaria: 37 pp.

Received: January 2008

Accepted: March 2008 